\title{
THE HEADSCARF PROBLEM IN TURKEY IN THE CONTEXT OF DISCUSSIONS ON FREEDOM
}

\author{
Derda Küçükalp \\ Uludağ University, Bursa-Turkey
}

\begin{abstract}
Both supporters and opponents of the headscarf ban in Turkey refer to the freedom of the individual. This case makes it necessary to address the headscarf problem in the context of discussions on freedom. This study aims to evaluate the headscarf problem in the context of two approaches that we call "the enlightened perspective" and "the liberal perspective." The enlightened perspective supports the headscarf ban in Turkey and is based on a particular interpretation of the idea of positive liberty. According to this interpretation, freedom means the manifestation of the rational self. Hence, people's freedom is connected with the sovereignty of their true lifestyle. Because religion equals "the irrational," the religious lifestyle is a deviation from the true way of life. For that reason, the use of the headscarf, which is a sign of a religious lifestyle, in the public sphere is seen as a threat to the correct lifestyle. The liberal perspective addresses the demand for the abolition of the headscarf ban in the context of the individual's freedom of belief. In this sense, it is possible to say that behind the liberal perspective's assessments about the headscarf issue lies the idea of negative liberty. Negative liberty means the lack of any outer intervention or pressure that limits the individual's choices and actions. The headscarf ban is a restriction for a woman who chooses a life in accordance with Islamic values and sees covering her body as a necessity for such a lifestyle. According to the liberal perspective,
\end{abstract}


wearing the headscarf must be seen as a lifestyle choice and thus respected. Allowing this choice is a requirement for freedom.

Key Words: Negative liberty, positive liberty, freedom, lifestyle, headscarf problem, liberal perspective, enlightened perspective, public sphere

\section{Introduction}

The beginning of the headscarf problem in Turkey dates back to the foundation of the Turkish Republic. Because the governing elites who founded the Turkish Republic regarded the secular life of society as a fundamental characteristic of "being modern," they saw the headscarf, like other religious symbols, as an opposition to modernity (and thus rationality). Through the implemented revolutions, these elites planned to put religion under the control of the state and turn a blind eye to religion in social life. Consequently, women covering their bodies were not seen as a problem in a certain section of society, which is placed in the "corner" of society, and have no effect on the center of social life. The headscarf started to become problematic when the above-mentioned section of society moved from the corner to the center as a consequence of political and social changes. This change was regarded as a threat to the Republic by a community that adopted the founding ideology of the Republic. This perception of threat strengthened over time and especially after the parties rooted in the Islamic tradition came to power. Consequently, we observed problems related to the headscarf issue in Turkey as follows: undergraduate students could not attend lessons while they covered their heads; public servants were not allowed to wear headscarves while on duty; students could not take examinations while wearing headscarves; and in public places with symbolic importance (e.g., the parliament and the presidential palace), the headscarf may have not be worn.

Both supporters and opponents of the headscarf ban in Turkey refer to the freedom of the individual. This case makes it necessary to address the headscarf problem in the context of discussions on freedom. This study aims to evaluate the headscarf problem in the context of two approaches that we call the enlightened perspective and the liberal perspective. While the first approach supports the headscarf ban, the second opposes it. The attitudes of the two approaches 
to the headscarf problem are directly related to their perception of freedom. Considering Isaiah Berlin's distinction, we can name these perceptions of freedom negative liberty and positive liberty. Berlin's distinction is especially important for us to understand how the community, which adopts the founding ideology of the Republic, reconciles freedom with pressure when they support the headscarf ban. In this study, we claim that the most appropriate grounds for the demands of the abolishment of the headscarf ban is the understanding of negative liberty, and we point out that the idea of positive liberty might work as a legitimizing factor for the headscarf ban.

When it is considered that liberal thought is fed by the idea of the enlightenment, one may think that the enlightened perspectiveliberal perspective distinction is problematic. However, enlightenment is often thought to make reason absolute and to legitimize the elimination of myth, tradition and religion, which are elements defined as "the opponent of reason" and seen as obstacles to enlightenment, by means of political power. There is a serious gap between this conception of the enlightenment and the liberal idea based on the classification of political power. ${ }^{1}$ We can say that, especially in non-Western societies such as Turkey, the idea of the enlightenment has been reduced to the above-mentioned form and perceived in this way. The belief of the elites who founded the Republic, namely that the enlightenment can only be applied by the elimination of tradition and religion, and their revolutionary actions related to this belief are a signs of how the enlightenment has been seen in Turkey. ${ }^{2}$ The idea of enlightenment in Turkey has given a higher position to the state rather than the individual and has functioned as a legitimizing factor for transforming society by means of the state. ${ }^{3}$ Because liberalism, by its essence, includes criticism of the state-oriented understanding, the liberal perspective has been a source for feeding liberals and any communities that announce their demands for freedom against the

Mustafa Erdoğan, Aydinlanma, Modernlik ve Liberalizm (Ankara: Orion Yayınevi, 2006), 38.

2 Mete Tunçay, “İkna (İnandırma) yerine Tecebbür (Zorlama),” in Tanıl Bora and Murat Gültekingil (eds.), Modern Türkiye'de Siyasî Düşünce, Cilt 2: Kemalizm (Istanbul: İletişim Yayınlar1, 2001), 93-94.

3 Mehmet Ali Kılıçbay, "Atatürkçülük ya da Türk Aydınlanması," in Ali Yaşar Sar1bay and Ersin Kalaycıoğlu (eds.), Türkiye'de Politik Değişim ve Modernleşme (Bursa: Dora Yayıncilik, 2009), 240. 
state. Conservatives and Islamists have generally taken the liberal perspective's idea of individual freedom as their starting point. However, there is a perspective in Turkey that does not consider the headscarf as an issue of individual freedom and instead claims that the real meaning of the freedom of the headscarf can only be found in an Islamic order of society in which people fulfill their religious duties. Being the subject of a different discussion, we will not address this issue in this paper.

\section{The Enlightened Perspective}

In dealing with the headscarf problem, the enlightened perspective takes the idea of positive liberty as its starting point. The fact that the enlightened perspective sees the headscarf ban as a liberating action is directly related to certain qualities of the idea of positive liberty. Although the headscarf ban is not a necessary consequence of the idea of positive liberty, an interpretation of the idea of positive liberty might work as a legitimizing factor for the headscarf ban. The enlightened perspective adopts this interpretation.

Positive liberty is concerned with the source of control. ${ }^{4}$ According to the idea of positive liberty, freedom of the individual is based on the notion that the individual is the source of control. The individual can be considered free only if he/she wills his/her actions, that is, only if he/she is the lawgiver.

The notion of positive liberty is based on the idea of a dualist self. ${ }^{5}$ According to this idea, the self is divided into a "high" and a "low" part. In relation to this division, the idea of positive liberty defines freedom as the sovereignty of the "high" self. ${ }^{6}$ In the given meaning, freedom does not exist automatically. Rather, it depends on the existence of something else, i.e., only in those cases in which the "high" self possesses its own meaning. Because the "high" self gains its meaning through actions that allow individuals to actualize their potential, to be free is to be free "for something." The definition of "to

4 Isaiah Berlin, "İki Özgürlük Kavramı [= Two Concepts of Liberty]," (translated into Turkish by Mehmet Saygilı and Enis Oktay), Cogito 32 (2002), 212.

5 Berlin, "Introduction," Four Essays on Liberty (Oxford \& New York: Oxford University Press, 1996), xliv.

6 Richard J. White, Nietzsche and the Problem of Sovereignty (Urbana, IL: The University of Illinois Press, 1997), 35-36. 
be free for something” proposes a positive relationship between freedom and pressure and connects freedom to inner factors such as the level of consciousness, the capacity for knowledge, feelings, and wishes. ${ }^{7}$ Once the importance and liberating function of pressure are accepted, it becomes more clear why not every limitation means "not to be free" in the idea of positive liberty. If freedom means that individuals do what they really wish ${ }^{8}$ and not that everybody does everything they want, it is necessary for us to limit the wishes coming from our "low" self to do what we really wish.

According to the enlightened perspective's logic, one woman's wish to cover herself is a sign that the woman's low self is determining her wish. Hence, if that person had acted according to her rational self, i.e., her reason, she would have known that the headscarf is a tool for controlling women, and thus she would not have covered her body. In this case, the wish for covering is a result of false consciousness, not free choice. According to the enlightened perspective, this false consciousness originates from false information, value, and behavior patterns that the person received by means of socialization. The recovery from this false consciousness is possible only with correct education. Once a woman receives this education, she realizes that the headscarf ban serves freedom. The "convincing rooms" of the $28^{\text {th }}$ of February are a result of this idea. These convincing rooms were created to inform students of the realities of the headscarf ban and lead them to uncover their heads voluntarily.

The equivalent of the distinction between the "high" self and the "low" self at the political level is the distinction between the selfrealization of the individual and the social conditions inconsistent with this realization. Parallel to the idea that one must control the "low" self and put pressure on it for the sake of the sovereignty of the "high" self, is the political meaning of positive liberty, which holds that the social conditions must be controlled and social life must be interfered with in order for people to master and realize themselves. It is accepted that pressure is not a completely negative thing but has

Karl Schmidt, "Freedom and Democracy," The Journal of Philosophy 39/14 (1942), 373.

8 Charles Taylor, "Negatif Özgürlük Anlayışının Yanılgısı [= What's Wrong with Negative Liberty?]," (translated into Turkish by Özden Arıkan), Cogito 32 (2002), 261. 
a positive function when necessary. Therefore, similar to the fact that the individual's suppressing of the "low" self's wishes constitutes a condition of freedom, the restriction of the individual's choices by interfering in social life is seen a condition for real freedom in terms of the political meaning of freedom. The idea of positive liberty, with the positive meaning it attributes to the concept of interference, establishes a relationship between freedom and historical-sociological conditions. According to the supporters of positive liberty, the realization of freedom is related to the inner factors as much as to the outer factors, which determine important parts of the inner factors. Thus, freedom is only possible in proper historical, social conditions.

The enlightened perspective sees women covering their bodies as a manifestation of bigotry. From this perspective, it bases itself on the idea that Turkey has not yet reached a level of progress that corresponds to the social conditions supplying freedom to every individual in the society. According to the enlightened perspective, which sees secular life as the most fundamental character of a modern society, demands for the freedom to wear a headscarf in public space in Turkey is the result of the persistence of the religious understanding, which is supposed to be left behind in modern society. The fact that some communities in Turkey cannot understand the necessity of the headscarf ban for a society that allows people to be free is a result of the religious understanding mentioned above. Although the headscarf ban prevents a demand from being actualized and puts pressure on the choices of those who have this demand, this pressure has a liberating function because it is required for a modern society to exist. When this type of society is actualized, women's demands for covering their bodies cease because the religious understanding, which stands as an obstacle to people's gaining the right consciousness, loses its effect. The enlightenment perspective's concern that religious understanding dominates social life is behind the perspective's sensibility to proliferate the use of the headscarf in the public sphere. Thus, a "reactionist" political-social order is actualized in Turkey. The enlightened perspective does not oppose women covering their bodies if there is no threat to the social order, even if it regards this as a choice stemming from false consciousness. This idea suggests that the enlightened perspective excludes private space from the issue of the headscarf ban. However, related to the fact that the enlightened perspective sees the public sphere as a threat, it can reach beyond the public sphere, which is defined by the use of state power. The head- 
scarf ban's application to university students is an example. The enlightened perspective has supported the headscarf ban in universities based on an understanding of a public sphere that includes university staff and public servants who use public power and students who do not use public power.

If the "low" self, i.e., deceptive feelings and wishes, is left behind and the "high" self, i.e., reason, is consulted, the distinction between the "high" self and the "low" self reveals the "monist" character of positive liberty together with the assumption that the correct can be known for one or many. Thus, the clash between values or options can be eliminated. Monism, which demands absolute solutions, is the biggest enemy of pluralism. ${ }^{\text {? }}$

The monist character of positive liberty corresponds to the enlightened perspective belief that a woman not covering her body is a sign that she is living the correct lifestyle. In this sense, covering the body deviates from the correct lifestyle. According to the enlightened perspective, in the clash between two lifestyles, every rational individual agrees that the first type of lifestyle is correct. To choose the second type is irrational. The correct social order is the order in which the rational lifestyle is dominant. Therefore, the spread of irrational lifestyles should be prevented, even by means of restrictions. According to the enlightened perspective, this is the very reason that the headscarf ban as a precaution that prevents the spread of the headscarf in the public sphere is a consequence of rationality.

The enlightened perspective holds that the use of the headscarf in the public sphere is a threat to a correct social order for two reasons. The first threat is formulated on the concept of "social power," and the second is formulated on the concept of "political power."

According to the enlightened perspective, an increase in the number of women wearing headscarves in the public sphere will socially pressure those women who do not wear headscarves. This is parallel to the sovereignty of the idea that a "religious," "chaste," and "moral" woman is always a woman with a headscarf. This pressure can be seen in cases in which women with headscarves do not see women without headscarves as religious and ostracize them. It can also be seen in cases in which women who do not wear headscarves feel

9 Berlin, "Introduction," i. 
ostracized by the increasing number of women with headscarves in the public sphere. The enlightened perspective holds that this pressure leads to an increase in the number of women with headscarves in society. We can also talk about reverse social pressure, in which women who cover their bodies are seen as leading a reactionist way of life that dominates society. This parallels the increase of women who do not cover their bodies. Because the enlightened perspective sees "non-covering" as a prerequisite to rationality, it does not see this pressure as an obstacle to freedom.

The enlightened perspective supports the headscarf ban and holds that the headscarf is being used as a political symbol. For the enlightened perspective, the headscarf symbolizes a religious political system. Thus, demands for the freedom to wear a headscarf in the public sphere functions as a tool for actualizing a religious political system. Therefore, lifting the headscarf ban may not be supported by individual freedom. The enlightened perspective sees the maintenance of the headscarf ban as correct and rational, regardless of the fact that the majority of society thinks that the headscarf should be allowed in the public sphere. Hence, the enlightened perspective has objected, on the grounds that these actions would serve to found a religious political system, to the actions of the political powers, which represent the majority of the society, in their attempt to change the constitution and codes to allow the headscarf in the public sphere.

Although it is contrary to the majority will, the enlightened perspective sees the headscarf ban as necessary. Behind this attitude lies the monist character of the idea of positive liberty. Although positive liberty sees freedom as "somebody governing himself/herself," it can lead to results that contradict democracy, a system that is equal to the notion of "self-governing" at the political level. When its rationalist definition is taken into consideration, freedom signifies an action that is the result of the human will under the guidance of reason. Then, freedom in the political meaning signifies forming of the will under the guidance of the collective reason. ${ }^{10}$ However, this overlap between individual wills and the collective will or a lack of any departure from the collective will is possible in the ideal state. In the ideal state, people do not tend to dominate each other and agree on the

10 Friedrich August von Hayek, "Freedom, Reason and Tradition," Ethics: An International Journal of Social Political and Legal Philosophy 68/4 (1958), 234. 
rules that regulate the social life because they respect the principles of reason as rational individuals. According to the rationalist idea, the existence of pressure in a society is a sign of the existence of wills that deviate from the collective will, that is, a sign that the ideal state is not reached. ${ }^{11}$ In this case, freedom requires pressure be put on the non-rational for their own sake and rational rules to be forced on the non-rational. In the words of Berlin, the assumption of a single real solution makes positive liberty an ideological tool for authoritative regimes that are governed by the directives of the elite. ${ }^{12}$ The identification of the "high" self with indefinite identities such as institutions, nations, races, parties, and the enlightened power of society results in the possibility that a doctrine of freedom becomes a doctrine of authority. ${ }^{13}$

\section{The Liberal Perspective}

The liberal perspective addresses the demand for the abolition of the headscarf ban in the context of the individual's freedom of belief and worship. As a result, it sees the headscarf issue as a problem of individual freedom. In this sense, the idea of negative liberty lies behind the liberal perspective's assessments of the headscarf issue.

Negative liberty means the lack of any outer intervention or pressure that limits the individual's choices and actions. With the lack of intervention and pressure, it is not important for the idea of negative liberty whether these choices and actions can be realized or not. As Berlin states, negative liberty points to the lack of obstacles in the way of someone who decides whether he/she walks or not; freedom is related to how widely the door is open, not to whether he/she wants to walk or not, or to how far the way is. ${ }^{14}$ In this case, it is obvious that negative liberty is concerned with whether the opportunities are found for choice and action and not the nature of the choices and actions made. ${ }^{15}$

The concept of "opportunity" is crucial for some fundamental characteristics of negative liberty to be understood.

\footnotetext{
11 Berlin, "İki Özgürlük Kavram1," 226-227.

12 Ibid., 232-234.

13 Berlin, "Introduction," xliv.

14 Ibid., xxxix.

15 Ibid, xlii.
} 
First, the concept of opportunity reveals the meaning of "negative" in negative liberty. Opportunity exists by itself upon the absence of factors that eliminate opportunity. Thus, equating freedom with opportunity brings about the definition of freedom as "the lack of something." According to this meaning, to be free is to be free from something. This "something" can reveal itself as the intervention of an individual, group, or institution. In this sense, to be free is to have a space of motion that can be used with the "lack" of this intervention and in which certain action choices are to be found. ${ }^{16}$ Therefore, in terms of the idea of negative liberty, the amount of freedom of the individual is determined by how the wide the space of action is in which no intervention exists. ${ }^{17}$

The liberal perspective posits that the headscarf ban is an intervention leveled against the individual's space of motion. For the liberal perspective, covering the body is a result of individual choice. The headscarf ban is a restriction for a woman who chooses a life according to Islamic values and sees covering her body as a necessity for such a lifestyle.

Second, opportunity is independent of the individual characteristics of the one who uses it. That being so, the negative liberty conception of freedom is not related to inner factors such as the possession of inadequate or incorrect information or the ability to evaluate and make present choices. ${ }^{18}$ Because what eliminates the opportunities is the outer pressure or intervention, negative liberty is an "outer" liberty.

The liberal perspective posits that we should respect the choice to wear a headscarf without questioning the underlying causes. At this particular point, the above-mentioned understanding that addresses freedom without the inner factor is important. In this sense, the liberal perspective holds that banning the headscarf on the grounds that it is a choice depending on false consciousness is a restriction to individual freedom.

Consequently, an understanding of freedom based on the concept of opportunity proposes that freedom is not related to historical-

\footnotetext{
16 Berlin, "İki Özgürlük Kavramı," 206.

17 Ibid., 207.

18 Taylor, "Negatif Özgürlük Anlayışının Yanılgısı," 255.
} 
social conditions. In the idea of negative liberty, there is a clear separation between freedom and its conditions. In Berlin's words, "liberty is one thing, and the conditions for it are another." 19 Accordingly, factors such as the economic state of an individual, his/her level of education, and the social environment he/she lives in may not be appropriate allow for certain opportunities. However, as long as there is no intervention to remove these opportunities, he/she will be free in the negative sense. At first sight, a sharp separation between freedom and its conditions might be considered to be contrary to the definition of negative liberty that it is the lack of the outer obstacles. This is because the historical-social conditions that prevent the individual from using the opportunities in front of him/her are included in the scope of the outer obstacle in its widest meaning. However, the outer restrictions in negative liberty are not taken in this wide meaning. In the idea of negative liberty, the unintended restrictions (historical-social conditions) are seen as similar to natural restrictions and are not obstacles to freedom..$^{20}$ An outer obstacle's possession of a nature that eliminates freedom, that is, its perception as an intervention, is connected to the fact that it is previously thought and intended. ${ }^{21}$

The liberal perspective does not set a relationship between unintended outer conditions and freedom. Therefore, it posits that the headscarf choice is a respectable choice free from the historical-social conditions of the chooser. According to the liberal perspective, the headscarf ban may not be supported by such reasons as the backwardness of the society, the social conditioning that women who choose to cover their bodies undergo in the social environment in which they are raised, the women's lack of education, which would enable them to make rational choices, and the unseen pressure of the social environment that determines their choice to cover.

The idea of negative liberty makes the concept of opportunity important. When it is taken in the context of the relationship between

\footnotetext{
19 Berlin, "Introduction," iii.

20 Ian Carter, "Positive and Negative Liberty," The Stanford Encyclopedia of Philosophy (Spring 2012 Edition), Edward N. Zalta (ed.), http://plato.stanford.edu/archives/spr2012/entries/liberty-positive-negative (accessed March 30, 2012).

21 Berlin, "İki Özgürlük Kavramı," 206.
} 
politics and freedom, the case points to the fact that there is a fear of intervening politics that is based on the belief that what is correct and false and good and bad for human beings can be known and that society is organized accordingly. The thing that leads most thinkers who adopt the idea of negative liberty to lean on the concept of opportunity is the fear of totalitarianism, which signifies the extreme case of the idea of policy. ${ }^{22}$ Because liberals see the inconsistencies between rival values as an indispensable part of the human condition, they give importance to a definition of freedom based on choice or opportunity. As Honneth states, because the definition of freedom based on the concept of opportunity eliminates all pseudo-good willing reasons for intervention in life, it functions as a condition to feed pluralism. $^{23}$

According to the liberal perspective, different lifestyles reflect different choices. For these choices to co-occur in peaceful way, they must be respected equally. The liberal perspective holds that this can be achieved in a political system that is based on the priority of rights. The rights that the individual possesses by the virtue of being human provide him/her a space of motion (freedom) in which he/she follows special purposes (choices, benefits, "good"s). Nevertheless, the space in which the individual follows his/her special purposes is limited by other individuals' space of motion. Thus, rights constitute the natural space and limit of freedom. In this sense, it is possible to say that rights have superior status in social life when compared to the individuals' choices to lead a good life. In the liberal perspective, this is called the principle of the priority of the right over the good. This principle also is grounded in the principle of the impartiality of law, a principle that the liberal perspective regards as the system of rules based on the protection of rights. The principle of the impartiality of law, which means that the rules that regulate common life remain the same distance from all choices of life, is tantamount to the guarantee of individual freedom.

In the liberal perspective, the headscarf is perceived as a threat to freedom only if it is imposed on people. This imposition could be in the form of someone being forced to wear a headscarf by a person,

22 Taylor, "Negatif Özgürlük Anlayışının Yanılgısı," 258.

23 Axel Honneth, "Negative Freedom and Cultural Belonging: Unhealthy Tension in Political Philosophy of Isaiah Berlin," Social Research 66/4 (1999), 1068, 1071. 
group, or institution. There could be a system of law based on a particular lifestyle that could force women to wear a headscarf. If these two cases are absent, the headscarf must be seen as a lifestyle choice and thus respected. Allowing this choice is a requirement of freedom. When it is considered in terms of the discussions on headscarf in Turkey, the liberal perspective holds that the headscarf ban implemented on university students, public servants, and members of parliament is an unjust practice.

Impartiality is a principle that the liberal perspective sees as the guarantee of all individual freedoms, including the freedom to wear a headscarf. However, impartiality is an argument that has been used to defend the headscarf ban in the headscarf controversies in Turkey.

Some who think that the headscarf should be banned in universities take the argument of the impartiality of the public sphere as their starting point. Accordingly, the headscarf is a political symbol because it points to a common lifestyle. For that reason, the demand for the freedom to wear a headscarf in universities cannot be seen as a demand for freedom. Because the headscarf as a political symbol points to an Islamic political system in which women must cover their bodies, to allow the headscarf in such a public space as universities contradicts the principle of the impartiality of the public sphere. There were those in Turkey who defended the view that women with headscarf should not attend "the receptions of the Republic," which are held in the presidential palace during the celebrations of establishment of Turkish Republic, or that they cannot be in the parliament while they wear a headscarf. These people have used the argument that no political symbol should be used in the public sphere. The liberal perspective holds that the headscarf ban may not be seen as legal, even if the headscarf is used in the public sphere as a political symbol. According to the liberal perspective, individuals have the freedom to act in the public sphere, either in an individual or organized way to spread their political views as long as they do not use force. $^{24}$

The headscarf ban directed to public servants is supported on the grounds of the impartiality of public institutions or individuals who use the public power. According to the supporters of this view,

24 Atilla Yayla, "Ahlak, Hukuk ve Başörtüsü Yasağ1” www.liberal-dt.org.tr (accessed March 30, 2012). 
someone who uses the public power wearing a headscarf contradicts the principle of the impartiality of the public power because the headscarf represents a certain way of life. Basing itself on the distinction of "givers-receivers of the public service" in the headscarf ban, this idea holds that the headscarf ban can be implemented only on those engaged in public service. For instance, this idea considers the headscarf ban for students as a violation of freedom. However, this perspective does not oppose the implementation of the ban on the university staff. According to the liberal perspective, the use of a symbol that represents a certain way of life by public servants does not contradict the principle of impartiality. If the public servants are unbiased towards the receivers of the service, the law rules must be considered because these rules give directions to them. If these rules are impartial and implemented on everyone equally, the dress of those who implement them is not important at all. ${ }^{25}$ The liberal perspective is based on the idea of negative liberty. Thus, it holds that an argument that a non-covered woman would see herself under pressure against a covered, public servant cannot be the reason for the implementation of the headscarf ban on public servants.

One of the arguments used to support the headscarf ban is the principle of the impartiality of rules. This principle posits that the rules needed to maintain order in social life should be applied to everyone equally. Accordingly, to exempt anyone from these rules for any reason is a violation of the principle of impartiality. The headscarf ban during examinations in Turkey has also been supported on the basis of the argument of the impartiality of rules. The supporters of this ban claim that some rules are needed in order for the success of the examination. Thus, they say that the headscarf ban is a rule put in place for identifying students in examinations. For the supporters of this claim, to allow some people to wear headscarves in examinations is to exempt those people from this rule, and this is contrary to the principle of impartiality. In fact, the principle of the impartiality of rules is a principle to which the liberal perspective also gives importance. Nevertheless, the liberal perspective regards the headscarf ban as a violation of freedom because of this principle. According to the liberal perspective, the rules that maintain the social order can be seen as legal, as much as they are dependent on human rights. If a rule limits a right and the individual's freedom that is granted to

25 Ibid. 
him/her in terms of this right, the application of this rule equally does not mean that justice is served. ${ }^{26}$

\section{Conclusion}

The enlightened perspective, which supports the headscarf ban in Turkey, is based on a particular interpretation of the idea of positive liberty. According to this interpretation, freedom means the manifestation of the rational self, i.e., the "quintessence" accepted as the common and fundamental characteristic of all mankind. Hence, people's freedom is connected with the maintenance and sovereignty of a lifestyle that allows the "rational" soul to exist, i.e., the true lifestyle. Because religion equals "the irrational," the religious lifestyle is a deviation from the true way of life. For that reason, the use of the headscarf, a sign of a religious lifestyle, in the public sphere must be seen as a threat to the correct lifestyle. The way to eliminate this threat is to ban the headscarf in the public sphere.

The perspective that adopts the idea of negative liberty, however, sees the demand to wear a headscarf in the public sphere as a demand for freedom. According to the liberal perspective, to be free means that there to be no interference in the individual's space of choice. It is a prerequisite of freedom that an individual forms his/her own life as he/she wants according to his/her wishes as long as he/she does not interfere in another's space of freedom. Wearing a headscarf is a lifestyle choice and thus the headscarf ban in the public sphere is a violation of freedom. According to the liberal perspective, an individual can question his/her own choice in parallel with his/her own choice of lifestyle. However, in the liberal political system, this questioning cannot go as far as to block the choices of the individuals who choose wearing a headscarf as a part of their lifestyle. This is because, for the liberal perspective, the headscarf choice must be respected as much as the choices of those who question it.

Undoubtedly, the liberal political system, which is based on the idea of the negative liberty, is an important guarantee for the freedom of the headscarf as much as for other types of freedom. However, is this guarantee enough, as the liberal perspective claims? I think that this guarantee is not enough because of an important factor that the liberal perspective ignores because it adopts the negative perspec-

26 Ali Yaşar Sarıbay, Demokrasinin Sosyolojisi (Istanbul: Timaş Yayınları, 2012), 70. 
tive. Although having a space of motion free from interference is important for the protection of the individual against pressure, this is not adequate for such protection. This is because pressure does not consist of only interferences, i.e., the intended outer factors. The unintended outer conditions that limit the individual's choices are also included in the scope of pressure. Because the idea of negative liberty does not differentiate between freedom and the conditions of freedom and because it ignores the relational character of freedom in social life, it is blind to the unseen face of pressure. ${ }^{27}$ For that reason, the idea of negative liberty ignores the fact that freedom can be lost in some cases without interference. ${ }^{28}$ For example, even if we live in a liberal political system, we cannot prevent a teacher, who sees the headscarf as a symbol of reactionism, from despising a student wearing a headscarf, preventing this student from uncovering her head and feeling worthless because of this despise. This shows us that freedom, i.e., the ideal of the liberal perspective, can only be actualized in a social system where the liberal culture dominates. Thus, disappearance of the headscarf problem in Turkey depends upon the change of the political culture rather than the legal or constitutional amendments. Because such a change of political culture cannot take place overnight, the headscarf issue will still be a topic of discussion in Turkey's near future.

\section{REFERENCES}

Berlin, Isaiah, "Introduction," Four Essays on Liberty (Oxford \& New York: Oxford University Press, 1996), i-lxiii. "İki Özgürlük Kavramı [= Two Concepts of Liberty]," (translated into Turkish by Mehmet Saygill and Enis Oktay), Cogito 32 (2002), 202-253.

Carter, Ian, "Positive and Negative Liberty," The Stanford Encyclopedia of Philosophy (Spring 2012 Edition), Edward N. Zalta (ed.), http://plato.stanford.edu/archives/spr2012/entries/liberty-positivenegative (accessed March 30, 2012).

27 William L. McBride, "The Concept of Liberty Thirty Years Later: A Sartre-Inspired Critique," Social Theory and Practice 16/3 (1990), 320.

28 Philip Pettit, Cumburiyetçilik: Bir Özgürlük ve Yönetim Teorisi [= Republicanism: $A$ Theory of Freedom and Government] (translated into Turkish by Abdullah Y1lmaz; Istanbul: Ayrıntı Yayınları, 1998), 60-61. 
Erdoğan, Mustafa, Aydinlanma, Modernlik ve Liberalizm (Ankara: Orion Press, 2006).

Hayek, Friedrich August von, "Freedom, Reason and Tradition," Ethics: An International Journal of Social Political and Legal Philosophy 68/4 (1958), 229-245.

Honneth, Axel, "Negative Freedom and Cultural Belonging: Unhealthy Tension in Political Philosophy of Isaiah Berlin," Social Research 66/4 (1999), 1063-1077.

Kılıçbay, Mehmet Ali, "Atatürkçülük ya da Türk Aydınlanması," in Ali Yaşar Sarıbay and Ersin Kalaycioğlu (eds.), Türkiye'de Politik Değişim ve Modernleşme (Bursa: Dora Press, 2009), 233-242.

McBride, William L., "The Concept of Liberty Thirty Years Later: A SartreInspired Critique," Social Theory and Practice 16/3 (1990), 297-322, http://dx.doi.org/10.5840/soctheorpract199016315

Pettit, Philip, Cumburiyetçilik: Bir Özgürlük ve Yönetim Teorisi $[=$ Republicanism: A Theory of Freedom and Government] (translated into Turkish by Abdullah Yılmaz; Istanbul: Ayrintı Yayınları, 1998).

Sarıbay, Ali Yaşar, Demokrasinin Sosyolojisi (Istanbul: Timaş Yayınları, 2012).

Schmidt, Karl, "Freedom and Democracy," The Journal of Philosophy 39/14 (1942), 365-381, http://dx.doi.org/10.2307/2018624

Taylor, Charles, "Negatif Özgürlük Anlayışının Yanılgısı [= What's Wrong with Negative Liberty]," (translated into Turkish by Özden Arıkan), Cogito 32 (2002), 254-275.

Tunçay, Mete (2001), "İkna (İnandırma) yerine Tecebbür (Zorlama)," in Tanıl Bora and Murat Gültekingil (eds.), Modern Türkiye'de Siyasî Düşünce, Cilt 2: Kemalizm (Istanbul: İletişim Yayınları, 2001), 92-96.

White, Richard J., Nietzsche and the Problem of Sovereignty (Urbana, IL: The University of Illinois Press, 1997).

Yayla, Atilla, "Ahlak, Hukuk ve Başörtüsü Yasağ1," www.liberal-dt.org.tr (accessed March 30, 2012). 